Dunaetz, D. R. (2017). A missionary's relationship to sending churches: Communal and exchange dimensions. In G. Hartt, C. R. Little, \& J. Wang (Eds.), Churches on mission: God's grace abounding to the nations. (pp. 303323). Pasadena, CA: William Carey Library.

\title{
A MISSIONARY'S RELATIONSHIP TO SENDING CHURCHES: COMMUNAL AND EXCHANGE DIMENSIONS
}

\author{
David R. Dunaetz \\ Azusa Pacific University
}

\begin{abstract}
The relationship between a career missionary and a local church should enable each member in the relationship to better accomplish the purposes to which God has called each one. However, the missionary-church relationship can be very complex, even confusing. The concepts of exchange relationships (where relationship members are expected to provide comparable benefits to each other) and communal relationships (where benefits are given to the one member without expectations of receiving something of equal value in response) provides a framework for understanding some of the dynamics of missionary-church relationships. Although a communal relationship may be a biblically-based goal, many aspects of missionary-church relationships can be understood as exchange relationships, which are also modeled and encouraged in the Bible. Ensuring that each member benefits from this relationship may make the relationship more stable during times of transition and distress.
\end{abstract}

When Joshua and Ashley were first appointed with their mission to a church planting ministry in Central Asia, they were thrilled and honored to be chosen to represent Christ in a country where the gospel had barely taken root. Their first responsibility was to raise financial and prayer support from friends and churches with whom they could share their vision. As millennials this was scary, but doable. Having been successful in everything they had always tried, they counted on God's grace for this undertaking. Sharing their vision and raising support from friends and other individuals with whom they could develop a relationship seemed fairly natural (after an initial period of hesitation). However, as they tried to develop relationships with local churches which had a history of supporting missionaries from their mission, they were not very sure of how to proceed. How bold should they be in asking for support? What did they have that they could offer churches? What did the churches expect of them?

When several churches began supporting them, the questions continued. Should they continue to develop the relationship with these churches or should they explore others? And once they arrived on the field, they still wondered about their relationships with the half dozen churches supporting them. What did the churches expect of them? How should they maintain the relationship? Should they let the churches know how difficult life was for them? Several years later, on their first "home assignment," Joshua and Ashley were still puzzled. How much time should they spend with their churches? How honest should they be about the difficulties they were experiencing on a notoriously discouraging field? Could they expect their churches to help more than they currently were?

To understand some of the issues that Joshua and Ashley need to deal with, as well as some of the concerns that members of Joshua and Ashley's supporting churches might have, we will examine several types of relationships that have been identified by social psychologists. These relationship types will 
provide a framework for understanding some of the important factors that missionaries should keep in mind in their relationships with their local churches. Missionaries, of course, live in a complex network of relationships that include relationships with various people in their home culture, other missionaries, and people in their host culture. This study is limited to describing one small fraction of these relationships: missionaries and people in their supporting churches.

It should be noted that the social sciences present many frameworks that can be used to understand mission-related phenomena. For example, from social psychology, social identity theory (Hogg 2006; Dunaetz 2015) and organizational justice theory (Dunaetz 2010c, 197-221; Colquitt et al. 2001) have provided frameworks that has been applied to missiological topics. From the field of leadership, transformational leadership theory (Riggio et al. 2004) and leader-member exchange theory (Graen and Uhl-Bien 1995) are examples of theoretical frameworks have many important missiological applications. None of these frameworks in themselves describe all mission related behavior, and without integrating biblical revelation, they are not capable of giving a complete description of how humans ought to behave. In this study, social exchange theory (Cropanzano and Mitchell 2005) will be examined, specifically applied to relationships (Clark and Mills 2011, 232-250), in order to better understand how human nature plays out in missiological contexts.

\section{Communal Relationships}

A communal relationship is a relationship where at least one member responds to the other's needs non-contingently, that is, without condition (Clark and Mills 1979; Clark and Mills 2011, 232-250). A parent's relationship with a baby is a relationship that corresponds closely to the ideal of this model. Parents typically respond to a baby's needs without the requirement or expectation that the baby responds in kind or even thanks the parents for responding to his or her needs. A young couple in love typically has a communal relationship as well. One partner does not keep track of the past responses of the other before meeting a perceived need. Each partner is intrinsically motivated to meet the other's needs out of love for one another.

Communal relationships are thus characterized by a concern for the other that is similar to the Christian concept of God's $\dot{\alpha} \gamma \alpha \dot{x} \eta \eta$ love (Jn. 3:16; Rom. 5:8). Just as God loves humans unconditionally and sent his Son to respond to their need, a member of a communal relationship will respond to the other's needs unconditionally. Similarly, Christians are to respond to one another with unconditional love (Rom. 13:810; I Cor. 13:1-13).

This would seem to imply that Joshua and Ashley should seek to have a communal relationship with their sending churches. Shouldn't the sending churches respond unconditionally to the needs of the young missionaries, and shouldn't Joshua and Ashley also respond unconditionally to the needs of their supporting churches?

If Joshua and Ashley had a 100\% communal relationship with their supporting churches, all the resources (including financial) that the churches possessed would be available for Ashley and Joshua and all of Joshua and Ashley's resources (including their physical presence) would be available for the churches. However, in most situations, this is not possible. Churches are constrained by their budgets and Joshua and Ashley will not be able to commute between their supporting churches and Central Asia very often. The relationship between Joshua and Ashley and their supporting churches is different than a communal relationship between a parent and a child or between a husband and wife. It is, in fact, quite different. Neither Joshua and Ashley nor their churches can realistically expect the other to track and attempt to respond to all their needs. Although a communal relationship might be ideal, the limited resources of each party do not allow for this possibility. 
It should be noted that these limitations in no way reduce the Christian responsibility to love God and other Christians with all the resources that one has. Whether one has one, five, or ten talents, the Christian is responsible for using them all for all God's service (Matt. 25:14-30). Acknowledging one's limitations is simply a means of recognizing one's humble condition, a necessary condition for serving God (Rom. 12:1-3).

\section{Exchange Relationships}

In contrast to communal relationships, exchange relationships are characterized by an expectation that both parties will provide comparable benefits to each other (Clark and Mills 1979; Clark and Mills 2011, 232-250). Exchange relationships may be characterized by material exchange (e.g., hiring a plumber to unclog a drain), but most exchange relationships among people who know each other are better described by social exchange (Cropanzano and Mitchell 2005), an exchange of non-material benefits such as approval, trust, esteem, or support.

In the New Testament, various exchange relationships are assumed to play an important role in the life of believers. Employers must faithfully fulfill their commitments to their employees (James 5:1-6). Within the Christian community, Christians are expected to have mutually beneficial relationships, characterized by honoring one another (Rom. 12:10), serving one another (Gal. 5:13), and being kind and compassionate to one other (Eph. 4:32). Able people who do not contribute to their own needs are to be excluded from the benefits of being part of the Christian community (2 Thess. 3:10-15). An especially important example of an exchange relationship is seen in Paul's appeal to Philemon to liberate his slave Onesimus, "If he has done anything wrong or owes you anything, charge it to me. ... I will pay it back-not to mention that you owe me your very self. I do wish, brother, that I may have some benefit from you in the Lord" (Philem. 1719, NIV).

Just as Paul and Philemon could expect, or just as a pastor and a church can expect a mutually beneficial exchange (e.g. salary and status for providing godly and biblical leadership to the church), Joshua and Ashley's churches might expect the young couple to faithfully proclaim the Gospel and make disciples in an unevangelized area in exchange for their financial and prayer support. Similarly, Joshua and Ashley will carry out their ministry, report on the progress they make and the difficulties they encounter, and visit their supporting churches every few years in exchange for their continued support. If for some reason either Joshua and Ashley or one of their churches can no longer carry on this exchange, the other party will most likely graciously understand. The relationship will either end or, at least, become significantly different.

Although most likely neither party would want to sit down and define a contract or explicitly state that there are expectations that must be met for the relationship to continue ${ }^{1}$, understanding that Joshua and Ashley's relationship with their supporting churches has many characteristics of an exchange relationship can help them understand how they should interact with their supporting churches. It can also help their supporting churches better understand how to manage their limited resources to best respond to Joshua and Ashley's needs.

\footnotetext{
${ }^{1}$ However, such contracts may exist. A biblical example is found in Acts 15 where the Council of Jerusalem requires gentile converts to abstain from certain behaviors (but not to be circumcised) in order for the relationship to continue in good standing.
} 


\section{Benefits Missionaries and Churches Provide to Each Other}

Although an exhaustive list is not possible because of the unique situation and characteristics of both missionaries and churches, there are several layers of benefits that missionaries and churches provide to each other. There are both explicit and implicit reasons that missionaries and churches may enter into a relationship. None of these reasons would be true in every relationship between a missionary and a supporting church, but they may serve as examples illustrating the complex nature of these relationships.

The explicit reasons churches support missionaries include strategically spreading the gospel, making disciples among unevangelized people groups, and participation in relief and development ministries. However, there are other benefits that missionaries provide churches that are often not stated. Missionary families often serve as a model of a committed Christian family; in many churches, missionary families are the only families who are regularly invited on stage or who have their family portraits distributed via prayer cards and publicity materials. Missionaries also provide churches with ministry opportunities for short-term missions. Many youth groups seek to coordinate short-term travel and ministry opportunities with missionaries whom the church supports.

Missionaries also provide supporting churches encouragement and affirmation of the churches' values. Stories told by visiting missionaries serve as evidence of the gospel's universal relevance, affirming the foundational values of church members. Photos of missions work, especially relief work, provide motivating visuals for fundraising and offerings; it is easier for a church to collect an offering by mentioning relief work in a drought-stricken country than the salaries of the pastoral staff.

In special situations, missionaries may provide affirmation for doctrinal and theological distinctives of specific churches or denominations. A missionary church planter with a long history of success in evangelism and disciple-making was once told by a supporting church that funds would be cut unless he spent a certain number of hours per week reading and studying the Bible. This fit the missionary's theological framework, so he agreed to the commitment and the church responded by a very large increase in support. In another situation, a church went through a doctrinal shift and asked their missionaries to sign the new confession of faith which included a blanket condemnation of the present-day use of sign gifts, attributing their presence to Satan. Missionaries who refused to support the new confession of faith were cut from the budget.

The reasons that missionaries develop and maintain relationships with churches are typically stated less explicitly. It is generally accepted that within North American evangelical culture, apart from some specific denominations, missionaries must raise support from interested churches and individuals. The request for financial support is typically implicit when a missionary contacts a church. Nevertheless, it is acceptable, and even expected, for missionaries to specifically request prayer for their ministry. An explicit request for prayer support affirms both the missionary's and the church's belief in the omnipotence and benevolence of God. In contrast, explicit requests for financial support can make the missionary come across as selfcentered or insensitive to the church's limited resources.

Emotional support is an important benefit that churches provide to missionaries. A church may send gifts or visitors to the missionaries while they are on the field, providing an opportunity to connect to their home culture and enjoy aspects of it that are not available in their host culture. Similarly, some churches may send short term teams who may provide a useful service for the missionary. When the missionaries are on home assignment, the supporting churches may also provide affirmation through public presentations involving the missionaries. In general, the affirmation provided to the missionary is proportional to the status of audience (speaking to adults is more affirming than speaking to children), the size of the audience (Sunday morning worship service versus a home Bible study group), and the length of time allotted to the missionary's presentation. 


\section{Understanding Exchange Relationships}

By understanding that their relationships with their supporting churches have many characteristics of exchange relationships, Joshua and Ashley can better understand how to maintain and develop these relationships. Several important phenomena which apply to exchange relationships have been empirically studied in social psychology such as cost-benefit analyses, power imbalances, relationship alternatives, and relationship investments (Kelley and Thibaut 1978; Emerson 2006; Cropanzano and Mitchell 2005). If Joshua and Ashley understand how these phenomena are likely to play out in their relationships with their supporting churches, they can better understand what they need to do to develop and maintain satisfying relationships with their churches, reducing (but not eliminating) the confusion and uncertainty that are associated with missionary-church relations.

\section{Cost-Benefit Analyses}

Studies in social exchange theory (Kelley and Thibaut 1978; Kelley et al. 2003; Cropanzano and Mitchell 2005) have demonstrated that exchange relationships are maintained and developed when both parties view themselves as net beneficiaries in a cost-benefit analysis. A cost-benefit analysis is traditionally a tool used to determine if a business action should be undertaken or not. If the benefits are greater than the costs, then it will be a profitable enterprise. The costs and benefits associated with relationships range from the material to the emotional (Lawler 2001). The costs and benefits associated with entering into a relationship predict whether or not people will choose to enter into a relationship with each other. If the benefits of being supported by First Church are greater than the costs associated with the relationship, Joshua and Ashley will want to enter into a relationship with the church. Similarly, if the benefits to First Church outweigh the costs, First Church will want to enter into a relationship with Joshua and Ashley. Once they have entered into a relationship, the desire to maintain it will be greater if the cost-benefit analyses performed (typically subconsciously) by First Church and by Joshua and Ashley are both positive.

For Joshua and Ashley, this means that they need to demonstrate that they are worthy of support. They need to communicate a clear vision of what they believe God is calling and enabling them to do. Before they leave for Central Asia, they need to demonstrate through their vision and the ministry opportunities that they have in First Church that they will be worth more than the cost of money and prayer that First Church will provide them. Once they are supported, they need to clearly communicate what the benefits of their ministry are: what they see God doing, who is being changed by the gospel, how the gospel is taking root in their host culture. If the benefits for First Church outweigh the costs, the church will desire to continue the relationship.

Although cost-benefit analyses may seem cold and calculated when applied to relationships, the Bible provides several examples which assume that a social exchange analysis is rational and appropriate. Moses concluded that the costs and benefits of being identified with the people of God outweighed the costs and benefits of $\sin$ (Heb. 11:25). Jesus told several parables illustrating the costs and benefits of the Kingdom of God (the parable of the pearl of great price, Matt. 13:45-46 and parable of the hidden treasure, Matt. 13:44). He encouraged potential disciples to count the cost of following him (Luke 14:25-33). The costs of discipleship include forsaking family and wealth, but the benefits are a hundred times as valuable and include eternal life (Matt.19:16-30). Jesus' teaching that it is better to give than to receive (Acts 20:35) is an especially important illustration of social exchange: The social and psychological benefits of giving outweigh the material costs involved and are even greater than the receiver's benefits. 


\section{Power Imbalances}

In a typical relationship between a church and a missionary, the missionary needs the church more than the church needs the missionary. It is much easier for a church to find a missionary to support than for a missionary to find a supporting church. It may take several years for missionaries to build their support base before they can move overseas. However, churches may have several missionaries contact them each week seeking support. In the relational theory of power, the power that Person 1 has over Person 2 is defined as the degree to which Person 2 is dependent on Person 1 (Emerson 1962; Cook et al. 2006, 194-216; Wilmot and Hocker 2011, 115-117). Since Joshua and Ashley are more dependent on First Church than First Church is dependent on Joshua and Ashley, First Church has more power in the relationship. Joshua and Ashley will be more concerned about maintaining the missionary-church relationship than First Church will be.

Power imbalances have a number of important effects on the lower power member of the relationship (Keltner et al. 2003). First, people with low power in a relationship tend to experience more negative emotions than high power people. Second, they become very sensitive to threats from the other party in the relationship. In Joshua and Ashley's case, this means they are likely to be afraid if they sense anything negative happening in their relationship with their supporting churches. If someone from one of the churches is offended by something in a prayer letter or social media, or by something they say on home assignment, this will likely be a source of distress for them since it could potentially mean losing the church's support. Certainly, missionaries must always speak and act with integrity. But there is always a risk that whatever they say or do may be misinterpreted. However, "God has not given us a spirit of timidity, but of power and love and discipline" (2 Tim. 1:7, NASB). Such a situation of weakness thus provides new opportunities to trust him.

A third consequence of low power is inhibited behavior (Keltner et al. 2003). Joshua and Ashley will want to continually make a good impression on their supporting churches and are likely not to share any information that would cast them or the effectiveness of their ministry in a negative light. They might be transparent about difficulties that they encounter (e.g., the difficulty of language learning or the people's resistance to the gospel), but they will not likely be transparent about their own weaknesses and mistakes (e.g., failing a language program or getting angry at a colleague). Such transparency could reduce their churches' perceptions of the benefits they are receiving from supporting Joshua and Ashley.

This means that Joshua and Ashley need to have close friends with whom they can share their struggles without the fear of rejection or damaging the relationship. This would most likely be a relationship with a peer on the field where there is no power imbalance (such as a fellow missionary or a national pastor). It could also be with an empowering supervisor if Joshua and Ashley could be sure that they would not suffer negative consequences for sharing bad news. However, if the supervisor cannot be trusted to respond in an encouraging way, the power differential is likely to prevent such communication.

\section{Comparison Levels}

Social exchange theory predicts that missionaries and churches are more likely to form and maintain relationships if the benefits for each party are greater than the costs. More precisely, the relationship will be satisfying if the benefits exceed the costs by a margin known as the comparison level (Thibaut and Kelley 1959, 21-24; Cropanzano and Mitchell 2005). This comparison level is the sum of all the expectations of what one party believes is the correct and appropriate net level of benefits that one should receive from the relationship. If the net benefits are less than the comparison level (less than expectations), the relationship will not be satisfying. For example, if a church expects Joshua and Ashley to regularly send encouraging prayer letters and to visit the church every few years, bringing their children to be seen on stage and to interact with others in Sunday School, Awana, and the foyer after the worship service, the church may not find the relationship very satisfying if Joshua and Ashley, in fact, leave their children with grandparents on 
most Sundays during home assignment.

The comparison level is thus the level of expectations that one party has for the other in order for the relationship to be satisfying, which increases the likelihood of it continuing. For missionaries, this means they need to learn each church's expectations and try to meet them. Each church may have different expectations and these expectations may change as pastoral staff and mission committees evolve. Joshua and Ashley thus need to get to know the expectations of each church that supports them. This may be difficult and time consuming, especially since the expectations change with time. In addition, once Joshua and Ashley begin to master their new Central Asian culture, understanding the expectations of their supporting churches may be even more difficult due to cultural interference (Mackey 2000, 26-54) in which knowledge gained from one culture interferes with being able to function in another in the most culturally appropriate way. Meeting with leaders from within their supporting churches, discussing expectations, and generally building up personal relationships are strategies that Joshua and Ashley can use to ensure that their relationships with these churches remain satisfying.

Social exchange theory also posits another comparison level, the comparison level for alternatives (Dunbar 2015; Thibaut and Kelley 1959, 21-24). This is the level of benefits that one could expect to have if one relationship is terminated in order to enter into another relationship. It is generally lower than the comparison level described above and sets the minimum level of satisfaction that one party must experience in order to maintain the relationship and not pursue another. For example, if First Church is disappointed in Joshua and Ashley's ministry, on-field communication, or home assignment presentations, they may consider supporting alternative missionaries instead. If there is a continual stream of attractive candidates who contact the church, the comparison level of alternatives may be relatively high. This means that not only should Joshua and Ashley try to meet the expectations of their supporting churches, but they should also try to provide benefits to these churches beyond what other missionaries seeking support can provide, especially if it is not possible to meet all of these churches' expectations. Although this may not be possible in every church, if Joshua and Ashley get to know the specific needs and expectations of their supporting churches and key leaders, they may be able to reach this goal with the churches that they know best.

\section{Investments}

We can summarize social exchange theory up to this point with simple mathematical models. These models are not meant to describe precisely how these various factors relate to each other. Rather, they simply show which of variables in question contribute to and which take away from the various outcomes. Many other variables influence these outcomes (ranging from personal differences in the people involved to divine intervention) which are not included in these models. In addition, we can only measure these variables roughly. God alone knows the true and ultimate value of all that we observe.

Our first model is an equation that gives a rough estimate of how satisfying a church-missionary relationship is:

$$
\text { Satisfaction }=\text { Benefits }- \text { Costs }- \text { Expectations (1) }
$$

The church-relationship will be satisfying if the benefits received from the relationship outweigh the costs, and if this net difference is greater than the expectations for the relationship (used as the comparison level).

This satisfaction can be used to predict if the relationship will be maintained or abandoned, in light of the alternatives: 
Each party will be committed to remaining in the relationship if the satisfaction obtained by a relationship (equation 1) is greater than the value of the alternatives (the comparison level for alternatives). If First Church believes that their relationship with Joshua and Ashley is more satisfying than would be a new relationship with some missionaries who could replace them in the budget, it is likely that Joshua and Ashley will continue to receive support from First Church.

However, when actually measuring human behavior, Caryl Rusbult of the Free University of Amsterdam (Rusbult 1980; Rusbult and Farrell 1983; Rusbult et al. 2011, 218-231) found that adding a third term, investment, to equation (2) produces a much more accurate model of human behavior over a wide range of contexts:

$$
\text { Commitment }=\text { Satisfaction }+ \text { Investment }- \text { Value of Alternatives }
$$

Investments refer to resources that are linked to the relationship and would be lost if the relationship would end (Rusbult et al. 1998). For a married couple, these investments might include happy memories, financial resources, possessions, common friends, respect in the community, and plans for the future. When the investment level is high, a couple is more likely to stay in a relationship. The same thing is true in other types of relationships, including missionary-church relationships. Investments might include memories and knowledge of each other, the church's financial investment in the missionaries, or visits made to the field by church members.

The range of investments can be quite broad, divided into two categories (Rusbult and Farrell 1983). Intrinsic investments are valuable resources that have been spent for the sake of the relationship. This might mean the time and effort that the missionaries have given to the church as well as the money that the church has provided to the missionary. On a personal level, the time and effort given by the individual members of the church and by the missionaries to develop individual relationships within the church may also be considered intrinsic investments. Extrinsic investments are valuable resources that have developed over time and have become linked to the relationship. This would include shared memories of past interactions, a sense of identify that has developed, and foreseen future benefits such as the fulfillment of the missionary's vision for ministry.

An important application of this model relates to how missionaries can maintain a relationship with churches even during the difficult times where the benefits provided by the missionary are low. Since the time of Paul, missionaries have passed through very trying experiences ( 2 Cor. 4:8-9). This may be due to environmental and cultural stress (Dunaetz 2013), organizational dysfunction at the mission level (Dunaetz 2010c, 197-221), competition and conflict between organizations (Dunaetz 2010a), church dysfunction (Dunaetz 2008), missionary team dysfunction (Dunaetz 2010b), or many other problems that prevent missionaries from providing their supporters the hoped-for benefits of a fruitful ministry. If Joshua and Ashley experience trying times that prevent them from providing many benefits to their supporting churches, equation (3) indicates that the church will remain committed to them, even if other promising missionaries are knocking on the door, if the churches and the missionaries have made sufficient investments in the missionary-church relationship.

If, in fact, sufficient investments have been made in the church-missionary relationship, the relationship begins to take on characteristics of a communal relationship, the type of relationship where all resources are shared regardless of the benefits that the church or the missionary receive from each other. Even if the cost-benefit analysis is negative, the relationship will remain intact because of the commitment to the relationship. As noted earlier, a communal relationship approaches the biblical concept of love and would 
be the ideal type of missionary-church relationship. The principle limitation mentioned earlier was that both the churches and missionaries have finite resources. However, when sufficient investments have been poured into a relationship, all the existing resources become available for meeting the needs that arise. Thus it becomes clear for Joshua and Ashley, and for the sake of the mission to which God has called them, that they should do all they can to invest in the relationships with the churches who express an interest in supporting them.

\section{Applications}

While the foundation of all missionary action needs to be based on a biblical theology, other tools such as history or the social sciences provide insight into how one can best serve Christ in one's specific cultural and historical context. In $21^{\text {st }}$ century North America, social exchange theory is one such tool that can be used to describe relationships between missionaries and churches. Joshua and Ashley thus have several broad principles that they can use to help them decide how to best relate to the churches that support them. The first principle is that they should not assume that they have a communal relationship with their churches characterized by unconditional love and a complete sharing of resources. Rather, they should view their relationship as an exchange relationship, where both they and their churches have something that can benefit the other. Their relationship will be at least minimally stable if they provide mutual benefits to one another.

A second principle is that Joshua and Ashley should provide as many benefits as possible to their supporting (and potentially supporting) churches to make the relationship more attractive. They will want to ensure that any subconscious cost-benefit analysis done by a church would indicate that the benefits that come from supporting them, both financially and with prayer, are greater than the costs involved. The benefits that they can provide the supporting church are numerous: the evangelization of an unreached people group, warm personal relationships with people in the church, a vision of how the gospel can transform a culture, interesting Sunday School lessons for both children and adults, and any other services that they can provide the church. Joshua and Ashley thus need to learn what aspects of their ministry are valued by each of their churches and clearly communicate to them how they are bringing about the desired outcomes in their host country as well as how they can provide desired services to the churches when they are serving in their home country.

It can be noted that these first two principles are also applicable to churches. Churches need to understand their missionaries' contexts well enough to know what their needs are. They should respond to as many of these needs as they can, not just to the financial ones. This will make the relationship stronger and provide a greater sense of partnership in fulfilling the Great Commission.

A third principle for Joshua and Ashley is that they should invest in their relationship with their supporting churches so that the relationship continues even when they pass through difficult periods of life and ministry. This means getting to know the decision-makers, gatekeepers, and key communicators in the church, building relationships with them, and continually sharing their vision with them. As the membership of the church evolves over the years, they need to continue to meet and develop relationships with each succeeding generation of church leadership, especially the lead pastor, the missions pastor, and mission committee members, depending on the structure of the church.

A final principle is that they need to trust the Lord, even in a position of weakness. Because they probably need financial and prayer support from the church more than a church needs an additional missionary family, Joshua and Ashley are in a position of weakness. Rather than fretting about their relationships with the churches, they should proclaim their vision with confidence in the Lord and work wholeheartedly toward achieving it, committing themselves completely to their ministry and to loving those who support them. 


\section{References}

Clark, Margaret S. and Mills, Judson R. 1979. Interpersonal attraction in exchange and communal relationships. Journal of Personality and Social Psychology, 37, 12-24.

Clark, Margaret S. and Mills, Judson R. 2011. A theory of communal (and exchange) relationships. In: van Lange, P. A. M., Kruglanski, A. W. and Higgins, E. T. (eds.) Handbook of Theories of Social Psychology. Los Angeles, CA: Sage.

Colquitt, Jason A., Conlon, Donald E., Wesson, Michael J., Porter, Christopher and Ng, K. Yee 2001. Justice at the Millennium: A Meta-Analytic Review of 25 Years of Organizational Justice Research. Journal of Applied Psychology, 86, 425-445.

Cook, Karen S., Cheshire, Coye and Gerbasi, Alexandra 2006. Power, dependence, and social exchange. In: Burke, P. J. (ed.) Contemporary Social Psychological Theories. Stanford, CA: Stanford Social Sciences.

Cropanzano, Russell and Mitchell, Marie S. 2005. Social exchange theory: An interdisciplinary review. Journal of Management, 31, 874-900.

Dunaetz, David R. 2008. Transforming Chaos into Beauty: Intentionally Developing Unity in Church Plants. Evangelical Missions Quarterly, 44, 358-365.

Dunaetz, David R. 2010a. Christian cooperation and ministry effectiveness: Insights and applications from empirical research in group processes. Dharma Deepika: A South Asian Journal of Missiological Research, 14, 17-26.

Dunaetz, David R. 2010b. Good teams, bad teams: Under what conditions do missionary teams function effectively? Evangelical Missions Quarterly, 46, 442-449.

Dunaetz, David R. 2010c. Organizational Justice: Perceptions of Being Treated Fairly. In: Baker, D. and Hayward, D. (eds.) Serving Jesus with Integrity: Ethics and accountability in mission. Pasadena, CA: William Carey Library.

Dunaetz, David R. 2013. Finding Still Waters and Green Pastures: Understanding and Reducing Stress in Urban Church Planting. Great Commission Research Journal, 4, 235-250.

Dunaetz, David R. 2015. Three Models of Acculturation: Applications for Developing a Church Planting Strategy Among Diaspora Populations. In: Wan, E. and Pocock, M. (eds.) Diaspora Missiology. Pasadena, CA: William Carey Library.

Dunbar, Norah E. 2015. A review of theoretical approaches to interpersonal power. Review of Communication, 15, 1-18.

Emerson, Richard E. 1962. Power-Dependence Relations. American Sociological Review, 27, 31-41.

Graen, George B. and Uhl-Bien, Mary 1995. Relationship-based approach to leadership: Development of leader-member exchange (LMX) theory of leadership over 25 years: Applying a multi-level multi-domain perspective. The Leadership Quarterly, 6, 219-247.

Hogg, Michael A. 2006. Social identity theory. In: Burke, P. J. (ed.) Contemporary Social Psychological Theories. Stanford, CA: Stanford University Press.

Kelley, Harold H., Holmes, John G., Kerr, Norbert L., Reis, Harry T., Rusbult, Caryl E. and van Lange, Paul A. M. 2003. An atlas of interpersonal situations, Cambridge, Cambridge University Press.

Kelley, Harold H. and Thibaut, John W. 1978. Interpersonal relations: A theory of interdependence, New York, NY, John Wiley and Sons.

Keltner, Dacher, Gruenfeld, Deborah H. and Anderson, Cameron 2003. Power, approach, and inhibition. Psychological Review, 110, 265-284.

Lawler, Edward J. 2001. An affect theory of social exchange. American Journal of Sociology, 107, 321352.

Mackey, William F. 2000. The description of bilingualism. In: Wei, L. (ed.) The Bilingualism Reader. New York, NY: Routledge. 
Riggio, Ronald E., Bass, Bernard M. and Smith Orr, Sarah 2004. Transformational Leadership in Nonprofit Organizations. In: Riggio, R. E. and Smith Orr, S. (eds.) Improving Leadership in Nonprofit Organizations. San Francisco, CA: Jossey-Bass.

Rusbult, Caryl E. 1980. Commitment and satisfaction in romantic associations: A test of the investment model. Journal of Experimental Social Psychology, 16, 172-186.

Rusbult, Caryl E., Agnew, Christopher R. and Arriaga, Ximena B. 2011. The Investment Model of Commitment Processes. In: van Lange, P. A. M., Kruglanski, A. W. and Higgins, E. T. (eds.) Handbook of Theories of Social Psychology. Thousand Oaks, CA: Sage.

Rusbult, Caryl E. and Farrell, Dan 1983. A longitudinal test of the investment model: The impact on job satisfaction, job commitment, and turnover of variations in rewards, costs, alternatives, and investments. Journal of Applied Psychology, 68, 429-438.

Rusbult, Caryl E., Martz, John M. and Agnew, Christopher R. 1998. The investment model scale: Measuring commitment level, satisfaction level, quality of alternatives, and investment size. Personal Relationships, 5, 357-387.

Thibaut, John W. and Kelley, Harold H. 1959. The Social Psychology of Groups, New York, NY, Wiley and Sons.

Wilmot, William W. and Hocker, Joyce L. 2011. Interpersonal Conflict, New York, NY, McGraw Hill. 